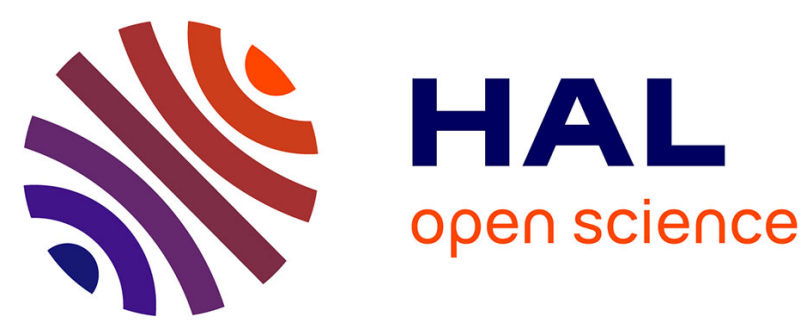

\title{
The spending multiplier in a time of massive public debt : the euro area case
}

Radu Vranceanu, Damien Besancenot

\section{To cite this version:}

Radu Vranceanu, Damien Besancenot. The spending multiplier in a time of massive public debt: the euro area case. 2012. hal-00728230v2

\author{
HAL Id: hal-00728230 \\ https://essec.hal.science/hal-00728230v2 \\ Preprint submitted on 14 Nov 2012
}

HAL is a multi-disciplinary open access archive for the deposit and dissemination of scientific research documents, whether they are published or not. The documents may come from teaching and research institutions in France or abroad, or from public or private research centers.
L'archive ouverte pluridisciplinaire HAL, est destinée au dépôt et à la diffusion de documents scientifiques de niveau recherche, publiés ou non, émanant des établissements d'enseignement et de recherche français ou étrangers, des laboratoires publics ou privés. 


\title{
The spending multiplier in a time of massive public debt : the euro area case
}

\author{
Research Center \\ ESSEC Working Paper 1209
}

2012

Radu Vranceanu

Damien Besancenot 
November 2, 2012

\title{
THE SPENDING MULTIPLIER IN A TIME OF MASSIVE PUBLIC DEBT: THE EURO AREA CASE
}

\section{Radu Vranceanu* and Damien Besancenot ${ }^{\dagger}$}

\begin{abstract}
This paper argues that in Euro-area economies, where the ECB cannot bail-out financially distressed governments, the fiscal multiplier is adversely affected by the amount of public debt. A regression model on a panel of $26 \mathrm{EU}$ countries over the period 1996-2011 shows that a 10 percentage point increase in the debt-to-GDP ratio is connected to a slowdown in annual growth rates of 0.28 percentage point. Furthermore, the effectiveness of fiscal spending is adversely affected by the amount of public debt; for a debt-to-GDP ratio above $150 \%$ the impact on growth of the fiscal stimulus turns negative.

Keywords: Fiscal multiplier, Euro-area, Public debt, Illiquidity, the Great Recession

JEL Classification: E62, G01, C23
\end{abstract}

Forthcoming in Applied Economics Letters, December 2012.

*ESSEC Business School and THEMA, PB 50105, 95021 Cergy, France. E-mail: vranceanu@essec.fr

${ }^{\dagger}$ University of Paris 13 and CEPN, 99 rue Jean-Baptiste Clément, 93430, Villetaneuse, France. E-mail: besancenot.damien@univ-paris13.fr 


\section{Introduction}

The 2007-2009 Great Recession left behind a dramatic legacy: creeping growth and high longterm unemployment rates, a devastated banking sector and huge public debts. Three years later, Euro area countries are facing the worst difficulties. Financial instability and poor growth are now compounding their effects in the most disruptive way. With ECB target interest rate close to zero, several economists echoed by many EU political leaders argue that only a massive fiscal stimulus can revigorate the weakest economies. The basic rationale behind this view builds on traditional Keynesian reasoning: low (short-term) interest rates combined with a depressed economy signal an excess of savings over investment opportunities; in this context, a higher public spending and the connected deficit should not push up interest rates, but stimulate growth (Krugman, 2010).

The Keynesian policy framework was developed under the assumption that bonds and money are perfect substitutes; in particular, bonds were seen as the risk-free asset. The contemporary DSGE new Keynesian macroeconomics also builds on the assumption that the central bank can maintain short and long-term interest rates on a pre-committed schedule (see Woodford, 2010). Yet these days are gone. Public debt is no longer seen as the perfect hedge against financial risks, in particular in Euro area countries where the central bank cannot monetize public debt. ${ }^{1}$ If the public debt is too high, small increases in this debt, triggered by fiscal stimulation of the economy, might bring about large variations in risk-adjusted interest rates. The culprit is the illiquidity risk: if investors lose confidence in a government and refuse to hold its debt, the debt service increases and pushes the debt on an unsustainable path. ${ }^{2} \quad$ As an example, in 2011 and 2012, Italy, one of the four largest Euro area economies, has seen yields on 10-year Treasury bonds crossing the $7 \%$ line for several times although it is running primary surpluses. Furthermore, in "high-risk" countries, risk premia on public and corporate debt are highly correlated (IMF, 2012).

\footnotetext{
1 The no-bail out orthodoxy of the ECB was somehow relaxed in September 2012, with introduction of the Outright Monetary Transactions programme. This new initiative allows the ECB to buy in the secondary market 3 -year bonds issued by of distressed governments.

2 See Besancenot et al. (2004) for a dynamic model where a small and remote risk of unsustainability can trigger imediate illiquidity default on public debt.
} 
In turn, higher corporate interest rates would entail the crowding-out of private investment. If the "financial crowding-out" effect takes over the direct public spending effect, the spending multiplier can be much smaller than one and even become negative.

In this paper, we aim to provide an analysis of the spending multiplier that takes into account the financial risk associated to large public debts. After introducing a spending multiplier that incorporates an additional "financial crowding-out" effect, we study the relationship between public spending, growth and public debt using a panel of 26 EU countries over the period 1996-2011. Both growth and the growth effect of a fiscal stimulus appear to be weaker in high-debt countries. Furthermore, the fiscal multiplier turns negative if the public debt raises above $150 \%$ of the GDP (with a lower bound of $108 \%$ at the $95 \%$ confidence level).

Recently several empirical papers have investigated the relationship between growth and debt in the long run. For instance Reinhart and Rogoff (2010) analyze data on forty-four countries over two hundred years. The show that the median growth rate is lower by one percentage point in countries/periods where the debt-to-GDP is above $90 \%$ as compared to countries/periods where the debt-to-GDP is below 90\%. Kumar and Woo (2010) analyze a panel of advanced and emerging economies over four years; they reveal a relationship between initial debt and growth: on average, a 10 percentage point increase in initial debt-to GDP is associated to a slowdown in annual real par capita GDP growth of 0.2 percentage point per year. Similar results were obtained for euro area countries; Checherita-Westphal and Rother (2012) and Baum et al. (2012) show that a debtto-GDP ratio above $90-100 \%$ brings about a negative impact on growth rates. There is no explicit model of for this negative relationship between growth and debt, but, as noticed by Cottarelli and Jaramillo (2012, p.9), who reviewed this empirical literature, "high debt is expected to result in lower growth because of crowding-out effects on private investment".

The paper is organized as follows. We firstly introduce a simple analysis of the spending multiplier that incorporates the financial crowding out effect. In the second part, we use data for EU countries in the 1996-2011 period, to gauge the impact of debt on both growth rates and the 
effectiveness of fiscal policy. The last section presents the conclusion.

\section{Theory: the "augmented" spending multiplier}

We start with the textbook IS condition:

$$
Y=c[Y-T(Y)]+I(i)+G,
$$

where $Y$ stands for the national income, $c$ is the marginal propensity to consume (constant), with $c<1, T$ are taxes as a function of income, with $d T / d Y=T_{Y}<1$, and $G$ denotes public spending. The public deficit is $D E F=G-T(Y)$. Private investment $I$ is is represented as a function of $i$, the interest rate on corporate projects, with $d I / d i=I_{i}<0$. The price level is assumed to be constant and inflation expectations are zero.

Let us denote by $\pi$ the (subjective) probability of default on the public debt and by $\rho$ the risk-free interest rate (constant). Without losing much explanatory power, we can assume that in the event of default the debt residual value is zero (i.e., the haircut is $100 \%$ ). With risk-neutral investors, the no-trade off condition implies a risk-adjusted interest rate on public debt $r$ defined by:

$$
1+r=\frac{1+\rho}{1-\pi}
$$

It turns out that the risk-adjusted interest rate on public debt is a convex, increasing function in the subjective default probability $\pi, r=r(\pi)$. We admit that this probability is an increasing function in the debt level $D$ and the deficit $D E F, \pi=F(D, D E F)$, with $\partial \pi / \partial D=F_{1}()>$,0 , and $\partial \pi / \partial D E F=F_{2}()>$,0 . We further assume that the cross derivative $\partial^{2} \pi / \partial D \partial D E F=F_{12}()>$, 0 : this assumption is quite plausible: if the debt is high, chances that a higher deficit pushes the debt out of the sustainable path should increase, and vice-versa.

In Europe, many corporations depend on public orders, subsidies and state guarantees. Under imperfect information, many investors use the country risk as a proxy for corporate risk, in particular for small, non listed firms. Furthermore, the best risk rating of companies is in general 
capped by the country rating; when a rating agency downgrades a country, the average cost of capital for corporations edges up (IMF 2012, p 39). ${ }^{3}$ Hence, we can assume that the interest rate on corporate debt and interest rates on public debt are strongly correlated, more precisely, we assume that risk-adjusted corporate interest rate can be represented as an increasing function in $r$, denoted $i=i(r)$.

Given this chain of effects, we can write the corporate interest rate as an increasing function in the public debt and the deficit:

$$
i=i(r(F(D, D E F)))=\varphi(D, D E F)
$$

with $\varphi_{1}>0, \varphi_{2}>0, \varphi_{12}>0$, properties that result from properties of the $F$ function.

A fiscal stimulus $d G>0$ brings about an impact on deficit, $d D E F=\left(1-T_{Y} \frac{d Y}{d G}\right) d G>0$. Since the variation in the debt is $d D=D E F$, a variation in deficit has only a second order effect (positive) on the debt that we will neglect.

Then, by differentiating the equilibrium condition (1):

$$
d Y=c\left(1-T_{Y}\right) d Y+I_{i} \varphi_{2}\left(d G-T_{Y} d Y\right)+d G
$$

we get the "augmented" public spending multiplier $\mu$ as:

$$
\mu=\frac{d Y}{d G}=\frac{1+I_{i} \varphi_{2}}{1-c\left(1-T_{Y}\right)+T_{Y} I_{i} \varphi_{2}} .
$$

The properties of the multiplier are easy to study:

- If we compare $\mu$ with the elementary multiplier $m=\left[1-c\left(1-T_{Y}\right)\right]^{-1}$, it can be easily checked that $\mu<m$. This is the direct consequence of the "financial crowding-out effect".

- Furthermore, if $m$ is allays larger than one, $\mu$ can be smaller than one (and even negative) if the crowding out effect is strong enough, which in turn depends on the response of investment to $i$, and the response of corporate interest rate to public debt changes: $\mu<1 \Leftrightarrow c<\left(-I_{i} \varphi_{2}\right)$.

\footnotetext{
${ }^{3}$ For instance, the correlation between the daily CDS spreads on 10-year Treasury bonds and the five biggest industrial corporations in Spain (a "high-risk" country), in the 2010.07-2012.07 period is 0.80. If including the two main banks, the correlation rises to 0.96 .
} 
- Given the $\varphi_{12}>0$ assumption, we have $d \mu / d D<0$ : the larger the debt, the bigger the impact of a fiscal stimulus on interest rate, and the more powerful is the crowding-out effect.

The purpose of this elementary analysis was to emphasize the financial crowding-out effect that can prevail when the debt-to-GDP ratio gets closer to the unsustainability limit, given investors' subjective assessment of the risk of default. The unsustainability limit has not been defined here, but is probably much lower for countries where the central bank cannot bail out the government, as compared to countries where the central bank can monetize public debt. A more powerful analysis would include the LM relationship, and the external sector. In an open-economy context, a higher financial risk would contribute to depreciate the currency, and might entail a positive effect on net exports.

\section{Empirical analysis}

The European Union is made up of 27 countries in 2011. The EU-27 debt-to-GDP ratio increased from $69.9 \%$ in 1996 to $82.5 \%$ in 2011 , with a strong acceleration after 2007 . Only six out of the 26 countries in our sample managed to reduce the debt-to-GDP ratio. The Appendix provides a summary of the data. Besides the 11 founding members who created the Euro in 1999, six other countries joined the club later on. In the light of our analysis, this is an important institutional change insofar as at that moment they become more vulnerable to the illiquidity risk. In the second semester of 2012 the debt-to-GDP ratio reached $90.0 \%$, compared to $71.6 \%$ at the creation of the European Monetary Union in 1999.

We estimate a growth equation, using panel on 26 EU countries over the period 1996-2011; we excluded Luxemburg given its special status and small population size. ${ }^{4}$ Data are provided by the Eurostat online database.

Denoting by GROWTH $H_{i t}$ - the annual real growth rate of country $i$ at time $t$, in percentage points; $D E F_{i t}$ - the public deficit as a percentage of GDP of country $i$ at time $t ; D E B T_{i t}$ - public

\footnotetext{
${ }^{4}$ Including Luxemburg does not change the results.
} 
debt as a percentage of GDP of country $i$ at time $t$; and DUMEMU - a dummy variable that takes the value 1 if the country is member of the Euro area, the growth equation is:

$$
G R O W T H_{i t}=C+a_{0} D E F_{i t}+a_{1} D E B T_{i t}+a_{2}\left(D E B T_{i t} \times D E F_{i t}\right)+a_{3} D U M E M U_{i t}+u_{i}+\epsilon_{i t}
$$

where $u_{i}$ is a country specific residual and $\epsilon_{i t}$ is the "usual" residual. The coefficient $a_{2}$ applies to an interaction term between debt and deficit.

We estimate equation (6) using both random and fixed-effect panel data estimators. The panel is strongly balanced; there are 405 observations ( 4 observations are missing for Greece (deficit, 1996-2001), 4 observations for Malta (growth, 1996-2001) and one observation is missing for Bulgaria in 1996). Table 1 presents the output of the estimation.

\begin{tabular}{||l|l|l||}
\hline \hline & Coefficients FE & Coefficients RE \\
\hline$D E F$ & $6.640^{* * *}$ & $5.991^{* * *}$ \\
\hline$D E B T$ & $0.959^{* * *}$ & $0.684^{* * *}$ \\
\hline$D E B T \times D E F$ & $-0.028^{*}$ & $-0.029^{* * *}$ \\
\hline$D U M E M U$ & $-2.103^{* *}$ & $-1.522^{* * *}$ \\
\hline & & \\
\hline$\sigma_{u}$ & 1.66 & 0.51 \\
\hline$\sigma_{\epsilon}$ & 2.93 & 2.93 \\
\hline$r h o$ & 0.24 & 0.03 \\
\hline$R^{2}$ & 0.22 & 0.23 \\
\hline \hline
\end{tabular}

Table 1. Output Estimates of the Growth Equation

$$
\left(* * *=\text { significant at } 1 \%{ }^{*}=\text { significant at } 10 \%\right)
$$

A Hausman test suggests that we can rely on the fixed-effect model to properly represent the country-level effects; for the sake of comparison we also provide the output estimate of the 
random-effect model. ${ }^{5}$

The regression model provides several interesting insights, in particular if we write the fitted growth equation (6) as:

$G R O W T H_{i t}=6.64-0.028 D E B T_{i t}+0.006\left(148-D E B T_{i t}\right) D E F_{i t}-2.103 D U M E M U_{i t}$

- All things equal, a 10 percentage point increase in the debt-to-GDP ratio would bring down the growth rate by 0.28 percentage point on average, a figure in line with the findings by Kumar and Woo (2010).

- In line with textbook Keynesian wisdom, if the debt-to-GDP is relatively low - here, below $148 \%$ (as calculated as the ratio of fitted coefficient $a_{0} / a_{2}$ ) - larger deficits (and higher spending) are associated to higher growth rates in the year when they occur. Hall (2009) reviewed the empirical evidence for the US and concluded that, under normal circumstances, GDP rises by roughly the amount of an increase in government purchases. According our estimates, this would happen in the EU region only if the debt-to-GDP ratio would be close to zero.

- Above the critical threshold of $148 \%$ debt-to-GDP, the impact of a positive deficit on growth rates turns negative. Notice that the $95 \%$ confidence interval for this critical debt-to-GDP is as large as $[108 ; 201] .^{6}$

- Notice also that the Euro area dummy seems to have a dramatic impact on growth. In other words, EU countries outside the Euro-area tend to outperform Euro member countries.

Of course, all these estimates should be interpreted with caution since they build essentially on linear relationships between the variables. The theoretical model has emphasized that the risk

\footnotetext{
${ }^{5}$ The Breusch and Pagan LM test indicates that the RE effect model is better than the pooled OLS estimator.

${ }^{6}$ The confidence interval of the ratio between the fitted coefficients is calculated with the Stata routine indicated at www.stata.com/statalist/archive/2010-04/msg00429.html
} 
premium and the interest rate might edge up very strongly if investors believe that the debt gets closer to the sustainablity threshold.

\section{Conclusion}

Whether fiscal stimulus can foster growth or not, it depends to a large extent on the response of long-term interest rates and the strength of the crowding-out effect on private investment. In this paper, we argue that the interest rate response depends on investors' assessment of the government's financial stability. For very large public debts, a positive deficit and additional debt might entail a substantial rise in interest rates and a very powerful crowding-out effect that can offset the direct effect of additional spending.

We back this rationale with empirical evidence on 26 European economies over the 1996-2011 period, which includes post-recession high-debt years. It turns out that a large public debt not only has an adverse effect on growth, but also reduces the positive effect of a given fiscal stimulus. More in detail, if the debt-to-GDP ratio exceeds a critical threshold with a central value of $148 \%$, the spending multiplier would become negative.

Policy implications are straightforward. For low public debt EU countries, fiscal policy can be an interesting tool, to be used with cautiously. However, if high-debt European economies want to stimulate growth, the most efficient solutions lie on the structural reforms side.

\section{References}

Baum, Anja, Cristina Checherita-Westphal and Philipp Rother, 2012, Debt and growth: New evidence for the euro area, Journal of International Money and Finance, Available online: 10.1016/j.jimonfin.2012.07.004.

Besancenot, Damien, Kim Huynh and Radu Vranceanu, 2004, Default on sustainable public debt: illiquidity suspect convicted, Economics Letters, 82, 2, pp. 205-211.

Checherita-Westphal, Cristina and Philipp Rother, 2012, The impact of high government debt on economic growth and its channels: An empirical investigation for the euro area, European Economic Review, 56, 7, pp. 1392-1405.

Cottarelli, Carlo and Laura Jaramillo, 2012, Walking hand in hand: Fiscal policy and growth in advanced economies, IMF Working paper, WP/12/137. 
Hall, Robert E., 2009, By how much does GDP rise if the government buys more output?" Brookings Papers on Economic Activity, 2, pp. 183-249.

IMF, 2012, Global Financial Stability Report. Restoring Confidence and Progressing on Reforms, October 2012, International Monetary Fund, Washington DC.

Reinhart, Carmen and Kenneth S. Rogoff, 2010, Growth in a time of debt, American Economic Review, 100, 2, 573-578.

Kumar, Manmohan S. and Jaejoon Woo, 2010, Public debt and growth, IMF Working Paper, $\mathrm{WP} / 10 / 174$.

Krugman, Paul, 2011, Mr. Keynes and the moderns, VOX, 21 June, Online: www.voxeu.org/ article/ mr-keynes-and-moderns.

Woodford, Michael, 2010, Simple analytics of the government expenditure multiplier, Prepared for the "Fiscal Stabilization Policy" session at the ASSA Conference, January 3-5. Available online: www.columbia.edu/ $\sim$ mw2230/G_ASSA.pdf.

Appendix. Summary statistics for 26 EU member countries

Note: (a) - 1997; (b) - 2001-2011. 


\begin{tabular}{|c|c|c|c|c|c|}
\hline Country & $\begin{array}{c}\text { Debt-to-GDP } \\
1996\end{array}$ & $\begin{array}{c}\text { Debt-to-GDP } \\
2011\end{array}$ & $\begin{array}{c}\text { Growth rate } \\
\text { Av.1996 - } 2011\end{array}$ & $\begin{array}{l}\text { Deficit-to-GDP } \\
\text { Av. } 1996-2011\end{array}$ & $\begin{array}{l}\text { EMU } \\
\text { (year) }\end{array}$ \\
\hline Austria & 68.1 & 72.2 & 2.2 & 2.2 & 1999 \\
\hline Belgium & 127.2 & 98.0 & 1.9 & 1.5 & 1999 \\
\hline Bulgaria & $108.3^{(a)}$ & 16.3 & 2.6 & 0.1 & - \\
\hline Cyprus & 53.1 & 71.6 & 3.0 & 3.3 & 2008 \\
\hline Czech Rep. & 11.9 & 41.2 & 2.8 & 3.9 & - \\
\hline Denmark & 69.4 & 46.5 & 1.3 & 1.0 & - \\
\hline Estonia & 7.6 & 6.0 & 5.0 & 0.2 & 2011 \\
\hline Finland & 57 & 48.6 & 2.8 & 1.9 & 1999 \\
\hline France & 58 & 85.8 & 1.7 & 3.5 & 1999 \\
\hline Germany & 58.5 & 81.2 & 1.4 & 2.3 & 1999 \\
\hline Greece & 99.4 & 165.3 & 1.9 & 7.7 & 2001 \\
\hline Hungary & 72.4 & 80.6 & 2.3 & 5.3 & - \\
\hline Ireland & 71.7 & 108.2 & 4.7 & 3.0 & 1999 \\
\hline Italy & 120.2 & 120.1 & 0.9 & 3.4 & 1999 \\
\hline Latvia & 13.9 & 42.6 & 4.5 & 2.5 & - \\
\hline Lithuania & 13.8 & 38.5 & 5.2 & 3.7 & - \\
\hline Malta & 40.1 & 72.0 & $1.7^{(b)}$ & 5.5 & 2008 \\
\hline Netherlands & 74.1 & 65.2 & 2.2 & 1.5 & - \\
\hline Poland & 43.4 & 56.3 & 4.4 & 4.7 & 1999 \\
\hline Portugal & 58.2 & 107.8 & 1.6 & 4.8 & 1999 \\
\hline Romania & 10.6 & 33.3 & 2.6 & 3.8 & - \\
\hline Slovakia & 31.1 & 43.3 & 4.3 & 5.7 & 2009 \\
\hline Slovenia & 21.9 & 47.6 & 3.1 & 3.0 & 2007 \\
\hline Spain & 67.4 & 68.5 & 2.7 & 2.7 & 1999 \\
\hline Sweden & 73.3 & $38.4 \quad 10$ & 2.7 & 0.7 & - \\
\hline UK & 51.3 & 85.7 & 2.3 & 3.4 & - \\
\hline
\end{tabular}


ESSEC Business School Avenue Bernard Hirsch BP 50105

95021 Cergy-Pontoise Cedex France

Tél. +33(0)134433000

$\mathrm{Fax}+33(0) 134433001$

www.essec.fr

\section{ESSEC Executive Education}

CNIT BP 230

92053 Paris-La Défense

France

Tél. +33(0)146924900

Fax +33(0)1 46924990

http:l/formation.essec.fr

ESSEC Business School

Singapore Campus

100 Victoria Street

National Library Building \# 13-02

Singapore 188064

essecasia@essec.fr

Tél. +6568849780

Fax +6568849781

www.essec.edu

\section{Informations}

Alison Bougi

+33 (0)134433358

bougi@essec.edu

unw.essec.fr

research.center@essec.fr

ISSN 1291-9616 